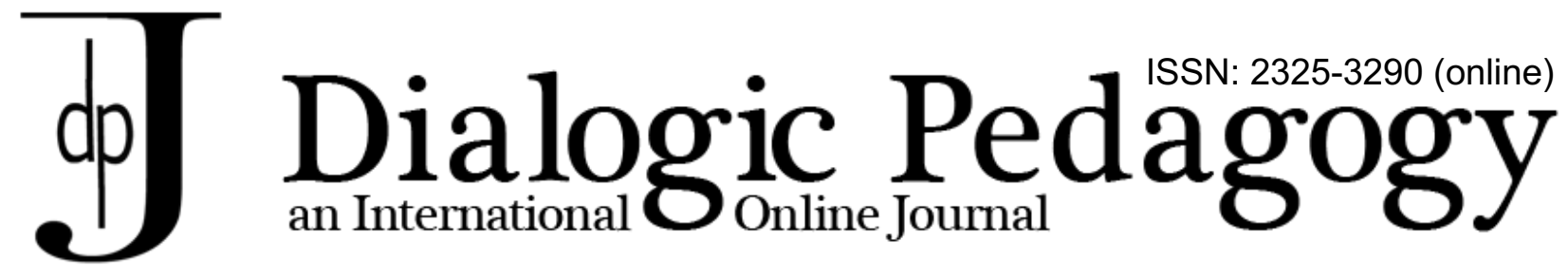

Whose discourse? Dialogic pedagogy for a post-truth world

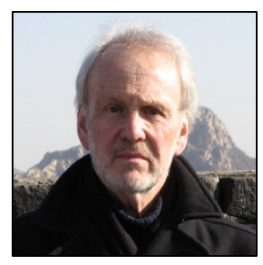

Robin Alexander

University of Cambridge, UK

\begin{abstract}
If, as evidence shows, well-founded classroom dialogue improves student engagement and learning, the logical next step is to take it to scale. However, this presumes consensus on definitions and purposes, whereas accounts of dialogue and dialogic teaching/pedagogy/education range from the narrowly technical to the capaciously ontological. This paper extends the agenda by noting the widening gulf between discourse and values within the classroom and outside it, and the particular challenge to both language and democracy of a currently corrosive alliance of digital technology and "post-truth" political rhetoric. Dialogic teaching is arguably an appropriate and promising response, and an essential ingredient of democratic education, but only if it is strengthened by critical engagement with four imperatives whose vulnerability in contemporary public discourse attests to their importance in the classroom, the more so given their problematic nature: language, voice, argument and truth. ${ }^{1}$
\end{abstract}

Key Words: Dialogue; pedagogy; democracy; language; voice; argument; truth

Robin Alexander is Fellow of Wolfson College, University of Cambridge, Professor of Education Emeritus at the University of Warwick, Fellow of the British Academy, and past President of the British Association for International and Comparative Education. He has held senior posts at four UK universities and visiting positions in other countries. He directed the Cambridge Primary Review, the UK's biggest enquiry into public primary/elementary education, and has worked extensively in development education, especially in India. His research and writing, whose prizes include the AERA Outstanding Book Award, explore policy, pedagogy, culture, primary schooling, comparative and development education, with classroom talk a prominent subset culminating to date in the successful large-scale trial of his framework for dialogic teaching. www.robinalexander.org.uk

$\cos (\sin 80$

\title{
The story so far
}

In 2011, scholars converged on the University of Pittsburgh to consider the claims of dialogic education in light of recent research. The evidence was succinctly summarised by the seminar's convenors:

Students who had experienced ... structured dialogic teaching performed better on standardised tests ... some students retained their learned knowledge for two or three years ... in

\footnotetext{
${ }^{1}$ This paper is an edited version of the author's keynote at the EARLI SIG 20/26 conference Argumentation and inquiry as venues for civic education, held in Jerusalem in October 2018.
} 
some cases students ... transferred their academic advantage to a different domain. (Resnick, Asterhan and Clarke, 2015, p. 1, authors' italics).

Resnick then nominated prerequisites for taking dialogic teaching to scale:

Two major ... tasks face us. First, we need a larger empirical base for the claim that dialogic teaching is likely to be effective with all kinds of students in various settings and subject matters. Second, we need to find ways of training many more teachers who are willing and able to use academic dialogue as a major component of their teaching. (Resnick, 2015, p. 448).

In a subsequent evidence review, Park, Michaels, Affolter and O'Connor (2017) confirmed that dialogic approaches accelerate learning across students, grades and knowledge domains; but noting that such talk is still uncommon they warned of "a lack of shared conceptualisations of what [it] is and how best to characterise it". Yet Howe and Abedin (2013) had earlier found a "shared conceptual core", albeit with "divergence around the edges."

George Bernard Shaw may or may not have aphorised that "The biggest single problem in communication is the illusion that it has taken place", but if we wish to address the post-Pittsburgh agenda we should at least agree on what we are talking about. Dialogue comes to most European languages via Latin from the Greek dialogos, a conversation, and for some people conversation is all that dialogue ever means. But dialogue is also the exchange of ideas, while when heightened by focused effort it enables us to expose, explore and resolve competing points of view. Similarly, "argument" may be a mere statement or proposition, but it can also signify the making and testing of a case, a well-tempered debate between opposing viewpoints, or indeed an ill-tempered quarrel. In many languages other than English the words for argument in these contrasting senses are different, so there is less room for ambiguity. But the community of educational dialogue and argumentation is international, and translation, especially in the realm of ideas, is not an exact science, so we should treat such keywords with caution.

Back, therefore, to "dialogue" as conversation. Simple definition becomes complex concept at the point when the conversation acquires a purpose. Thereafter, dialogue is stance as well as process. In classrooms the stance is self-evidently relational, certainly epistemological, probably ethical and conceivably ideological, and both separately and in combination these properties intimate a barely containable plurality. In the research community some seek, evidentially or conceptually, to impose order by describing dialogue; others prescribe the form it should take. As for "dialogic teaching", it has both multiple stipulative definitions and a vaguely generic one. Stipulatively, I have used the term my way since the early 2000s, others use it their way, and whether the twain or many shall meet is a matter of chance. Generically, "dialogic teaching" can signify no more than talk that replaces IRF/IRE by discussion, without specifying that discussion's purpose or character. Indeed, used without explanation the term "dialogic teaching" may be little more than virtue signalling: IRF/IRE bad, dialogic teaching good.

The definitional differences that are most likely to confound even the illusion of communication are those that stem from disciplinary affiliations. The fact that talk, dialogic or otherwise, interests cognitive psychologists, sociologists, anthropologists, philosophers, psycholinguists, sociolinguists, ethnolinguists, pragmatists, comparative linguists, discourse analysts and conversation analysts might justify celebration that its importance is so widely recognised, except that this plurality reduces prospects for mutual understanding still further.

For disciplinary perspective, or what Park et al. (2018), following Emig, call a "governing gaze", determines what we look at, how we look at it, and what, having looked, we see. Then, in application, it 
shapes our view of what dialogue ought to be about. This paper started with the dialogic claim as validated by student performance in standardised tests in a small range of curriculum domains. But some hold that dialogue, argumentation and discussion serve other educational purposes that are no less important, while a case can be made for regarding these kinds of talk as of intrinsic value to the development of mind and culture regardless of what schools choose to teach and test. Dialogue, in short, may be a means or an end, a way of doing or of being (Matusov, 2018). It may be a pedagogy narrowly defined, a necessary educational goal which is at once pedagogical, epistemic and ethical, as commended in the Cambridge Primary Review (Alexander, 2010a, p. 199) or indeed an education in itself (Alexander, 2006).

Attempting to make sense of all this, Lefstein and Snell (2014) posit six quasi-paradigmatic dialogic concepts - or perhaps stances - each with its own questions, values and goals, and for good measure its own guru: dialogue as the interplay of voices (Bakhtin), as critique (Socrates), as thinking together (Vygotsky), as relationship (Buber), as empowerment (Freire), and as interactional form (no guru specified). Lefstein and Snell then juxtapose these stances with four models of dialogic practice: Nystrand's dialogically organised instruction (Nystrand et al., 1997), Mercer's exploratory talk (Mercer and Littleton, 2007; Mercer and Dawes, 2008), the "accountable talk" of Resnick, Michaels and O'Connor (2010), and Alexander's version of dialogic teaching (Alexander 2017).

Next, seeking to expose disagreement as well as consensus, Kim and Wilkinson (in press) compare the versions or visions of dialogic pedagogy of Freire, Burbules, Nystrand, Wells, Wegerif, Matusov, Mercer, Boyd, Reznitskaya, Mortimer and Scott, Juzwik, Lefstein and Alexander before identifying three "points of contention" that underlie the differences that emerge: the balance of significance given to linguistic form and function and the way, as explored by Boyd and Markarian (2015), that this relationship is perceived; the degree to which talk is embedded in the wider classroom culture or detached from it; and whether dialogic pedagogy is viewed as a specific way of organising classroom talk or as a general approach that can be implemented in different ways.

Conceptual differences such as those exposed in these reviews are marginal, pace Howe and Abedin, only if one concedes that dialogic pedagogy is little more than technique; a view perhaps reinforced by the use of standardised tests as the default measure of its effectiveness (see our opening quotation). Since it is evident that dialogic pedagogy can do, be and produce much more than this, the extent of a "shared conceptual core" remains open to question.

\section{A collision of discourses}

So what else can dialogue be and do? I now muddy the definitional waters further by registering what I see as a widening chasm between the ways of talking and reasoning that are cultivated inside the school, whether dialogic or non-dialogic, and those that students encounter outside it. Indeed, I want to propose that while the gradualist agenda for talk reform at scale extrapolated from the reviews cited above - clarify concepts, extend evidence, consolidate proof of concept(s), disseminate practice, improve training - pursues the leisurely logic of academic enquiry, it makes educational as opposed to technical sense only if it also confronts this socio-cultural collision of discourses.

Let me elaborate. For some students the norms of pedagogical, curricular and wider cultural discourse may be more or less in harmony. Others experience well-researched dissonances relating to class, race and gender; and they discover how academic and everyday registers diverge - inevitably so, for opening up new ways of knowing, understanding and hence of naming, expressing and communicating is the essence of schooling. 
But divergence has lately morphed into confrontation. On the one hand we have the sedimented habits and values embodied in school curriculum domains and the more or less rational and courteous ways of accessing, interrogating and verifying the knowledge that such domains embody. But on the other hand we witness the raucous free-for-all of social media, the ascendancy of ephemeral and anonymous online content over the verifiable and attributable knowledge of book and laboratory, the mischievous anarchy of fake news, the reduction of judgemental nuance to the binary "like"/"dislike", the trolling and abuse that for many people have replaced discussion and debate; and the sense not so much that truth claims are open to question, as of course they always should be, as that for many in the public and political spheres truth is no longer a standard to which they feel morally obliged to aspire.

As if to prove his immunity from this basic moral standard and pronounce the Overton window well and truly shattered, a democratically-elected American president can utter, according to the Washington Post, over 8000 "misleading or demonstrably false" statements since his inauguration in 2016, or an average of 11.3 public falsehoods each day, yet still be president. (Kessler et al., 2018; Washington Post, 2019).

At the time of writing, Trump's case is egregious but far from unique, for in extreme form he displays tendencies that have afflicted the leadership of many other countries that call themselves democratic, as well as those whose regimes are openly autocratic: the braggadocio, aggression and narcissism of the would-be alpha male; the manipulation of information; the appeals to people's worst instincts rather than their best; the stoking and exploitation of racism, misogyny and homophobia; the sustained attacks on the press, judiciary and other institutions of civil society that provide the checks and balances that good government requires. And, insidiously but dangerously, the erosion of what Levitsky and Ziblatt call the "soft guardrails" of democracy:

mutual toleration, or the understanding that competing parties accept one another as legitimate rivals; and forbearance, or the idea that politicians should exercise restraint in deploying their institutional prerogatives. (Levitsky and Ziblatt, 2018, p. 9).

UK legislators have begun to acknowledge the challenge posed by these trends. In 2018, a parliamentary select committee documented extensive evidence that digital media had been exploited to play to voters' fears and prejudices and influence their voting plans and behaviour in the 2016 US presidential election, the 2016 UK Brexit referendum, and elections in France, Germany, Spain, Africa and Latin America. Meanwhile, there was growing concern about the extent to which social media had come to dominate children's lives, skew their development and exploit their vulnerability. (O'Keefe and Pearson, 2011; Savage, 2019). The committee concluded:

Urgent action needs to be taken ... to build resilience against misinformation and disinformation into our democratic system ... Our democracy is at risk. Our education system should [equip] children with the necessary tools to live in our digital world, so that their mental health, emotional well-being and faculty for critical thinking are protected ... Digital literacy should be the fourth pillar of education, alongside reading, writing and maths. (House of Commons, 2018, pp. 3 and 62-3).

Children must certainly acquire the knowledge and skills necessary for coping in a digital world, but I am less sanguine about bolting digital literacy onto a curriculum that in other respects remains untouched. Conspicuously unchallenged is the belief that the so-called "3Rs" are the three immovable "pillars" of school education; and that this hoary definition, which shackled Britain's schools for the urban masses in the $19^{\text {th }}$ 
century but goes back 1400 years to St Augustine's "legere et scribere et numerare", can be made fit for the $21^{\text {st }}$ century by adding another "literacy" but without challenging the assumption that oracy is merely incidental.

Some see the task in terms of what England's national curriculum calls PSHE (personal, social and health education); others reach for the nostrums of civic education. Traditionally restricted to imparting received wisdom about the institutions of government and the values that are held to underpin them (in Britain officially defined as "democracy, the rule of law, individual liberty, and ... respect for and tolerance of those with different faiths and beliefs, and ... those without faith") (Ofsted, 2018), this version of civic education sanitises politics and idealises citizenship. Some might add that it confirms the school as instrument of cultural and economic reproduction (Bowles and Gintis, 1976; Bourdieu and Passeron, 1990), if not as full-blown "ideological state apparatus" (Althusser, 1976). There is little space in the traditional and somewhat Hirschian view of civic education for the awkward question, let alone for the critical pedagogy of a Freire or Giroux (Hirsch, 1988; Freire, 1970; Giroux, 2011).

The handling of talk in schools may be no less hegemonic. In Britain, exclusive and expensive private schools used to train the nation's future leaders in the art of public speaking and adversarial debate so as to send them into the world articulate, confident and ready to take control. This tradition goes back centuries to when classical and then renaissance rhetoric were fundamental to a gentleman's education. (Simon, 1966; Kennedy, 1999). Meanwhile, schools for the ungentlemanly majority (of either gender) pinned their faith on the $3 R$ s and at all costs avoided unleashing the subversive possibilities of talk. In Britain, the contrast between private education for leadership and state education for followership is still evident in the social and educational profiles of senior politicians, the private/state school opposition of liberal and instrumental curricula, and the struggle to persuade government to give spoken language the prominence in state schools that it deserves and defend it against the ministerial charge of "idle chatter". (Alexander, 2014; 2015).

Such conditions highlight the challenge facing those who believe, following Dewey (1997), that a deliberative democracy requires a deliberative pedagogy. For, as Kakutani says, "Without commonly agreed-upon facts ... there can be no rational debate ... Without truth, democracy is hobbled" (Kakutani, 2018, pp. 172-3). Equally, when immediately after the second world war George Orwell warned that "The present political chaos is connected with the decay of language" (Orwell, 1968, p. 139) he foreshadowed our own present, for the abuse of public language is symptomatic of what in some countries is a democratic malaise and in others is a crisis. And in considering where all this might lead we recall Hannah Arendt:

The ideal subject of totalitarian rule is not the convinced Nazi or the convinced Communist, but people for whom the distinction between fact and fiction ... and ... between true and false ... no longer exist. (Arendt, 2004, p. 474).

In light of all this, I suggest that consideration of the future of dialogic pedagogy might encompass not only the post-Pittsburgh agenda - conceptual clarification, evidence of impact, strategies for professional development - but also four new imperatives. They are language, voice, argument and, as a subset of the latter, truth. These provide the focus for the remainder of this paper.

\section{Language}

Cued by Orwell, we nominate language as the pivot. Language makes us human, powers thought, evokes learning, conveys culture, coheres community, and - for better or worse - tempers or inflames public discourse. 
We approach this first post-truth imperative by way of a pedagogy that explicitly links spoken language with democratic education and engagement. "Accountable talk" was first proposed by Resnick during the 1990s (Resnick et al., 2010) and developed with Michaels and O'Connor, who preferred the term "academically productive talk" (Michaels and O'Connor, 2015; Park, Michaels, Affolter and O'Connor, 2017). It has three interdependent facets. Accountability to community, later modified to accountability to the learning community, establishes and maintains the culture of classroom talk that is essential to collective sense-making and learning - listening, respecting others' ideas, building on each other's contributions and so on. Accountability to standards of reasoning "emphasises logical connections and the drawing of reasonable conclusions." Accountability to knowledge requires that speakers base what they say on "facts, written evidence or other publicly accessible information that all ... can access" (Michaels, O'Connor and Resnick, 2008).

This triple insistence on accountability - communal, rational, epistemic - speaks to the proper conduct of public and policy discourse no less than to that of teaching and learning. Michaels, O'Connor and Resnick acknowledge, as this paper does, the mismatch between what we strive for within classrooms and what students may encounter outside them; and "though ... we have made some progress in ... classrooms ... there is much we still do not know about how best to set up the conditions for truly democratic discourse on a wide scale." (Michaels, O'Connor and Resnick, 2008). Yet accountable talk remains a powerful ideal. It links classrooms with democratic practice not indirectly or by exhortation as in traditional civic education, but by being of itself participatory and deliberative; and it has been applied through a battery of talk moves for the third turn in ways that are both practical and successful (Michaels and O'Connor, 2012; 2015). ${ }^{2}$ Yet its authors speak of unfinished business, and in that spirit I propose a fourth strand: accountability to language, and specifically accountability to spoken language.

What do I mean by this? In the first instance, talk must be the object of learning as well as its medium. In the 2014-17 dialogic teaching project led by Frank Hardman and myself, "talking about talk" was the first of 11 cycles in a 20 -week programme combining professional development with teaching, mentoring and video analysis, and it remained prominent throughout. (Alexander, 2018). Similarly, Dawes, Mercer and Wegerif (2004) initiated their Thinking Together programme with a group of five lessons fronted by "talk about talk".

Out of such foundational activities can come, alongside ground rules for classroom talk of the kind with which we are all familiar, a heightened awareness of talk's possibilities; of the interplay between linguistic and paralinguistic aspects; of the dynamics of turn-taking; of code, register, accent and dialect and their social ramifications; of the relationship between discourse form, function and context; of the language of argumentation; and, salient here, of the nature, uses and impact of rhetoric.

Such metalinguistic understanding is sensitised and deepened through audio and video. Teachers in several of our projects have shared and discussed with their students the lesson videos they initially intended for their own self-study, with striking results. These teachers literally "made talk visible" to their students (QCA, 2004, p. 4). Ever the pioneer, Cazden was doing this, though with audio, several decades ago. (Cazden, 2001, p. 7).

However, video-prompted "talk about talk", if untutored, may concentrate more on talk's paralinguistic features than its structure and meaning, or what we see rather than what we hear (Alexander,

2 Sarah Michaels and Cathy O'Connor have kindly allowed me to use their 'talk moves' (Michaels and O'Connor, 2012: 2015) to boost the latest iteration of my dialogic teaching framework (Alexander, 2018), though I have renamed the moves 'extending' to emphasise their attention to the third turn. 
2017; Lefstein \& Snell, 2014). Carter's work on the grammar of talk rebalances the focus. Using computer corpora of naturalistic spoken English, he shows how written and spoken forms are different not only in obvious respects like formality and fluency but also in their structure, yet that sufficient consistencies emerge from corpus analysis of discourse markers, word order, ellipsis, deixis and incremental rather than subordinate clauses for the word "grammar" to be appropriate. (Carter, 1997; McCarthy and Carter, 2001).

Carter's grammar of talk is descriptive, not normative. It is an aid to understanding the relationship between conversational structure and meaning, not a manual for "correct" speaking, and in a country like the UK where debates about "correct" or "standard" English are sharply politicised this proviso requires emphasis. A grammar of talk begins to do for talk what literary analysis does for text. But it is only a beginning, and if talk is as important as we believe then we might also consider whether tools of discourse analysis used for researching the talk of teachers and students might feature in the education of students themselves, and indeed the place in the school curriculum of linguistic analysis of the kind hitherto confined to universities. These possibilities are now being actively canvassed in the UK (Crystal, 2018; CLiE, 2019).

Talking about talk applies equally in the context of democratic education, for leaving aside the question of whether we live in an Orwellian age of language decay, talk is the medium through which politicians engage with the electorate, even if at one stage removed via tweets and television debates. In the UK I have charted four signature discourses through which policies may be advocated and contrary views marginalised. The discourse of derision (Kenway, 1990; Ball, 1990), uses ridicule or abuse to discredit or at least neutralise ideas and evidence that are politically inconvenient. The discourse of dichotomy reduces complex issues to a binary choice between caricatured alternatives and the politics of them and us. The discourse of myth peddles inflated claims while belittling what others have achieved in order to lower the baseline against which delivery on policy promises will be set. And if the discourse of myth is about the destruction of the past, the discourse of meaninglessness destroys language itself, for it evades or obfuscates meaning, parades the old as new, but once unpicked collapses into a tangle of cliché and tautology. (Alexander, 2008; 2010b; 2014).

The discourses of derision, dichotomy, myth and meaninglessness transparently flout Grice's maxims governing the relation between logic and conversation: quantity (a contribution should give as much information as is needed and no more), quality (it should be well-founded and true), relation (it should be relevant) and manner (it should be clear and orderly in delivery) (Grice, 1975). Of course, such negative discourses may be offset by the judicious language, serious argument, defensible evidence and intelligibility to which politicians of integrity remain committed. Yet this everyday contrast underlines the argument that examining how political language works should be part of students' democratic education; just as, in their education as a whole, talk should be the object as well as the means of their study. Equally, having recourse to generic tests of the argumentative power and validity of language as used, such as those cited above by Grice and below by Walton and Toulmin, or with a specific focus on dialogic pedagogy (Reznitskaya and Wilkinson, 2017), or by the proponents of philosophy for children (Lipman, 2003; Fisher 2008; Gregory, 2007) can make talk a powerful tool for cultural and civic engagement no less than for learning more narrowly defined.

\section{Voice}

All I have is a voice / To undo the folded lie, / The romantic lie in the brain / Of the sensual man-in-the-street / And the lie of Authority / Whose buildings grope the sky. 
Thus wrote British poet W.H. Auden (1991), on September $1^{\text {st }} 1939$ : fateful day. Citizenship is the exercise of voice as well as vote. Citizens use their voices to argue for what they believe is right and against what they believe is wrong. Voice is where democracy starts, and voice is what autocracy seeks to stifle.

Like our other keywords, "voice" has several meanings. In life we speak, shout, scream, whisper or sing, and these contrasting physical exercises of our vocal cords express intentions, opinions, ideas, emotions, wants and needs: indeed, who we are. In classrooms Segal and Lefstein (2015) differentiate four senses of "voice": having the opportunity to speak; expressing one's own ideas; speaking on one's own terms; and being heeded. These stages in the progress of the classroom exchange, from permission to speak to acknowledgement of what is spoken, are about ownership and rights. Together, they prompt four questions. What do we do to encourage our students to speak? How do we ensure that what they say is treated equitably and respectfully? When they speak, whose voices do we hear? And how do we handle the contributions that don't follow our agenda?

Such questions are partly addressed in the literature on turns and turn-taking, ground rules, communities of discourse and communicative rights and competences (Edwards and Westgate, 1994; Mercer, 2000), so I concentrate here on the question about voice in the sense of ownership of what is said. Segal and Lefstein tell us that students in their study

enthusiastically contribute to lively classroom discussion and often frame these discussions as dialogical responses that build on each other's ideas, but at the level of voice the discussion is mostly univocal, since most student contributions are aligned with the official voice of the teacher and the curriculum and in the rare instances where they emerge, independent student voices fall out of the conversation. (Segal and Lefstein, 2015, p. 1).

The authors call this "exuberant voiceless participation", using voice in their sense of ownership of what is uttered. (See also Segal, Pollak \& Lefstein, 2016; Lefstein, Pollak \& Segal, 2018). While they acknowledge Bakhtin's much quoted maxim that "the word in language is half someone else's" (Bakhtin, 1986, p. 170), they find their observed teachers and students caught between competing epistemologies: on the one hand the principle of co-construction, on the other hand the "official knowledge" of the school curriculum. This dilemma, say Segal and Lefstein, is translated into teaching that may be dialogic in form but is monologic in function. Discussion, however lively and promising, reductively yields what the teacher expects and is therefore, in the authors' second and third senses, "voiceless".

The paradox of apparently open pedagogy mediating a closed curriculum was noted over 40 years ago in a piece by Atkinson and Delamont (1977) entertainingly entitled "Mock-ups and cock-ups: the stage management of guided discovery instruction". Yet I am not convinced that matters are this clear-cut, for if Bakhtin is right, then nobody, including the teacher, has an independent voice. Teachers initiate their students into ways of thinking and knowing developed by others, and their task is in large measure cultural transmission, and indeed - if we accept Basil Bernstein's classic definition of pedagogic discourse (Bernstein, 1990, p. 168) as "a relay for power relations external to [the classroom]" - social control. Viewed thus, even the goal of developing students' autonomous thinking, notwithstanding the confident claims of dialogists, is normative.

Yet while freedom is never absolute it can be tempered. The path from the official curriculum to the curriculum as enacted and experienced in the classroom is rarely linear. Governments may specify, but schools translate what is specified, teachers transpose it and together teachers and students transform or domesticate it (Alexander, 2001, pp. 552-3). It is through pedagogy that a paper curriculum gains life and 
meaning, and in this matter the agency of teachers and students is critical. Similarly, students learn more outside school than their teachers may credit (Mayall, 2010) and each student's unique out-of-school biography predisposes classroom contributions to the curriculum as translated and transposed that may be as much their own as the teacher's; though what each student brings to the learning encounter enters the dialogue only if the teacher allows it. But when the teacher does allow the student's voice in Segal and Lefstein's senses of speaking on one's own terms and being heeded, I see no contradiction between the dialogic dynamic and the school's obligation to advance the student's understanding in ways that have been culturally developed and are collectively understood.

If teaching may be dialogic in form but not necessarily in function, it may also be monologic in form but in its content more dialogic than at first sight it appears, for example when the teacher uses the expository mode conventionally associated with "traditional" teaching to introduce ideas of different kinds and from different sources in order to encourage corresponding dissonance in the mind of the student. (See the case study of one such teacher in Alexander, 2008, pp. 154-172). This teaching mode reminds us to differentiate inner from outer speech as well as, again, to avoid confusing form with function. (Wells, 1999; Boyd \& Markarian, 2015). Curriculum domains represent centuries of cumulative co-construction and are inherently dialogic; and while teaching that is behaviourally dialogic may explicate and celebrate the epistemic dialogue and monologic teaching may mask it, neither consequence is inevitable. (Cf Mortimer and Scott's discussion of the tension between authoritative and dialogic interactions in science teaching, Mortimer and Scott, 2003; and Nystrand's insistence that the bottom line is not the presence or absence of discussion, small group work and so on but the extent to which teaching, however configured, "requires students to think, not just report someone else's thinking" (Nystrand et al, 1997, p.72)). We should avoid treating dialogue and monologue as mutually exclusive. Epistemic and pedagogical dimensions transect; boundaries may be blurred.

No less important than the overall balance of teacher and student voice is the matter of vocal equity among students themselves, but re-casting equity as voice underlines its complexity. Consider this:

It is difficult for a woman to define her feelings in language which is chiefly made by men to express theirs (Hardy, 1916, p. 414).

At first sight this expresses a very modern consciousness about voice and patriarchy, and Dale Spender puts the matter almost identically:

Women have been obliged to use a language not of their own making ... women [have been allowed] to express themselves, but only in male terms (Spender, 1980, p. 12).

But what I quoted first was in fact written nearly 150 years ago, in 1874. And it was written by a man, British novelist Thomas Hardy, putting the sentiment about man-made language into the mouth of a woman, Bathsheba Everdene in Far from the Madding Crowd. So which version of Spender's or Hardy's or Bathsheba's statement about language and gender is "man made"? And while Spender offers explicitly feminist critique, what exactly is Hardy up to? Does he empathise with women's situation, or does he reinforce male dominance by attributing to men more power than they have? And does Dale Spender unwittingly do the same? Is it in fact male arrogance to assert that language is "man made", and double arrogance for a male novelist to put that assertion into the mouth of a woman?

I float the matter in this equivocating way because my final concern about voice is this. Many countries are deeply divided by inequalities of income, opportunity, education, class, race and of course gender. Among the promises of dialogic teaching is that it distributes classroom talk more equitably, first 
between teacher and students collectively, then among students themselves; and that this redistribution will contribute to the larger cause of reducing social inequality. That is why the UK Education Endowment Foundation were keen to support our trial of dialogic teaching with children meeting the criteria of social and economic disadvantage. ${ }^{3}$

Yet while dialogic teaching can be shown to shift the balance of classroom talk towards students collectively, we must ask how far it equalises the voices of different groups of students. If the word is indeed "half someone else's" does this maxim apply to every student equally, or is it the case that for some students theirs is a "silenced dialogue"? (Delpit, 1988; Edwards, 1989).

In reconciling cultural transmission, equity and the development of the student's autonomous (or normatively autonomous) thinking, much hangs on the third move in the spoken exchange. Here the seminal work of Michaels and O'Connor $(2012 ; 2015)$ reminds us that the third move has the power to ensure that the student's voice, once invited, does not "fall out of the dialogue" (Bakhtin, 1986, P 168). So to assess whether an exchange is genuinely dialogic, and whether it promotes student equity and autonomy, we might treat the third move as an indicator - while being ever mindful of the danger of inferring cognitive function from oral form.

\section{Argument}

In English, "argument" suggests bellicosity as well as rationality, and this is how many students view it (Osborne, 2015, p. 406; Kuhn et al., 2011). The norms of deliberative discourse are not instinctive but need to be made explicit and translated into ground rules (Mercer and Dawes, 2008). Argumentation is an acquired skill, and helping students to move from mere disagreement to evidentiary discussion is a necessary educational task. (Reznitskaya and Wilkinson, 2017).

It is hardly surprising if students view argument as conflict. They witness the media turning complex issues into battling binaries. They join a twittersphere that thrives on intolerance. They see politicians asserting cases rather than demonstrating them, using evidence selectively, and gleefully stoking disagreement into conflict. But the manipulation of evidence is among the oldest tricks in the political game, so rather than deplore this as an aberration students should learn that political and academic argument have different goals and conventions, and that when argument is about persuasion and power rather than truth, evidence gives way to rhetoric, and rhetoric has its own rules. (Condor, Tileaga \& Billig 2013).

Cicero, master of political rhetoric, said, "Wisdom without eloquence does little benefit"; though he did have the grace to add, "But eloquence without wisdom does much harm" (Kennedy, 1999, p. 94). Pertinently, there has been a revival of interest in classical rhetoric and its modern variants, especially in university English departments (Welch, 1990). The last great flowering was during the Renaissance, when the key texts of Aristotle, Cicero and Quintilian were rediscovered and in schools and universities the practice of rhetoric was as essential as the study of arithmetic, geometry and astronomy. (Simon, 1966). Rhetoric, too, guided and framed renaissance poetic discourse. Some of Shakespeare's greatest speeches and bouts of oral fencing, for example in Hamlet, can be properly understood only if one has a grasp of the

\footnotetext{
${ }^{3}$ Classroom Talk, Social Disadvantage and Educational Attainment: raising standards, closing the gap, directed by Robin Alexander and Frank Hardman and funded 2014-17 by the UK Education Endowment Foundation. The project entailed the development and independent randomised control trial, with nearly 5000 students in three English cities, of a professional development and support programme based on Robin Alexander's dialogic teaching framework. After just 20 weeks, students in the intervention group were up to two months ahead of their control group peers in standardised English, mathematics and science tests. The project is reported and discussed in detail in Alexander (2018), while there are accounts of, respectively, its interim internal evaluation and external RCT in Alexander et al (2017) and Jay et al (2017). https://cprtrust.org.uk/research/classroom-talk/
} 
rhetorical devices and figures of speech with many in Shakespeare's audiences were familiar (Adamson et al., 2007). Is this territory to which dialogic pedagogy might return us?

In any event, we cannot be content to frame our discussion of dialogic pedagogy and democratic engagement by polarising academic and political argument as if each were one-dimensional. Walton (2013), for instance, proposes seven types of dialogic argumentation, each with its own goals, moves, questions and responses: persuasion, inquiry, discovery, negotiation, information exchange, deliberation and eristic argument. The first six are reasoned and rule-bound, and only eristic argument (from the Greek word for "strife") aims to win by whatever means are available. Political argument can and often does entail negotiation, inquiry and deliberation, but the eristic is always there as the last resort or, for some, the first.

Prominent in eristic argument are the well-known fallacies of syllogistic reasoning: equivocation, or exploiting ambiguity; begging the question; ad verecundiam, or citing an "authority" who may be nothing of the sort; ad hominem, attacking the person rather than the argument; ad baculum, or threatening dire consequences if one's views aren't accepted; and so on. Some of these classic fallacies are numbered among Schopenhauer's "38 ways to win an argument" (Schopenhauer, 2004), which start from the proposition that logic pursues truth but eristic aims only for victory. Schopenhauer's list, published in 1831 but still resonant, includes alongside the familiar syllogistic fallacies some decidedly contemporary echoes: "make your opponent angry", "generalise from the specific", "claim victory despite defeat", "persuade the audience, not the opponent", "interrupt or divert the dispute if you think you are losing", "puzzle or bewilder your opponent by mere bombast", and "be personal, insulting and rude."

Just as academic and political argument are not mutually exclusive but overlap on a continuum, so academic argument is not one mode but many. Scientific, mathematical and historical reasoning, to take three obvious paradigms, are manifestly different. Less frequently considered in the dialogic pedagogy literature is argument in the artistic and literary spheres. How do we make or test the case for a work of art, music or literature? Between the 1930s and 1970s the influential Cambridge literary critic F.R. Leavis taught his students to attend as closely as possible to text, investigating and assessing the technical, linguistic and stylistic ingredients of prose, poetry and drama and locating them in historical context, so that they could distinguish the technically original and inventive from the mediocre or routine, and assign dates to samples of writing without knowing the author, which, like "blind" student grading, certainly aids objectivity.

But moving from assessments of artistic technique and style to judgements of artistic merit is more problematic. Here Leavis relied on his famous question "This is so, isn't it?" which puts a literary work's moral seriousness and psychological or experiential authenticity on the line alongside its technical and imaginative mastery. But "This is so, isn't it?" was always followed by "Yes, but...", an obligatory riposte that commands both convincing justification and rigorous scepticism about every judgement ventured, the literary equivalent of Popper's theory of scientific conjectures and refutations, perhaps (Popper, 1963). Of course, this process interrogates evidence of a kind and in a way that would be unlikely to satisfy a physicist, but that is the point: the modes of argument and justification in the arts and sciences are different but not necessarily of unequal validity.

As Reznitskaya, Wilkinson and their colleagues have shown (Reznitskaya \& Wilkinson, 2017; Reznitskaya, Kuo, Glina \& Anderson, 2009), Toulmin offers a kind of reconciliation. Noting that different kinds of question or claim call for different treatment, he proposes a generic "layout" of six elements of argumentation applicable to most circumstances: claim (what has to be established or proved); ground (facts, evidence, data or reasoning in support of the claim); warrant (justification for the grounds cited); backing (additional or alternative support); qualifier (limitations on the claim); and rebuttal (counter- 
arguments). This applies as well to Leavis's approach to literary judgement as to the scientific/mathematical examples that Toulmin cites, such as "whether ... Fröhlich's theory of super-conductivity is really satisfactory, when the next eclipse of the moon will take place, or the exact nature of the relation between the squares on the different sides of a right-angled triangle." (Toulmin, 2003, pp.12-13).

This is the briefest of canters across a vast and complex field to which others, notably Schwarz and Baker (2017), have devoted the depth and multi-disciplinary breadth that it deserves; while Reznitskaya and Wilkinson have devised an "argumentation rating tool" that identifies four key criteria of "quality argumentation" and tracks these through 11 "facilitation practices" (Reznitskaya \& Wilkinson, 2017, pp 4046). Learning in general, and learning for democratic engagement in particular, require us to be able to make, understand and test arguments of different kinds. The task is larger than even a totally reconfigured civic education programme can accomplish. It requires us to think about dialogue and democratic education across the curriculum as a whole, and hence in epistemic as well as pedagogical terms. Approached through dialogue rather than recitation, curriculum domains come into their own as ways of arguing as well as knowing, and taken together they can enhance the student's capacity to make, understand, critique and challenge argument outside as well as inside the classroom.

\section{Truth and trust}

"Comment is free, but facts are sacred" was the mantra of C.P.Scott, legendary one-time editor of the then Manchester Guardian. Nowadays the boundary between objective fact and subjective opinion is more blurred than in 1921, and not only in the media and body politic: in academic life, too, it is contested. Indeed, academics may be unwittingly implicated in attacks on received truth by epistemic nihilists in the White House and Westminster. "People have had enough of experts", declared England's former Education Secretary Michael Gove of those who cited hard evidence to challenge populist claims about migration and economic impact promulgated by Brexit advocates in 2016; and "truth isn't truth" said presidential attorney Rudi Giulani, to gasps of outrage even louder than those that greeted Kellyanne Conway when she defended as "alternative fact" President Trump's exaggeration of the size of the crowd at his 2017 inauguration. But Kakutani (2018) shows how such tropes do not so much come out of the blue as take to extremes the post-modernist rejection of the enlightenment belief in objective reality, provable truth, stable linguistic constructs and reason itself.

Habermas noted that there is an inherent contradiction in using traditional methods of reasoning and arguing to attack those same methods of reasoning and arguing. (Habermas, 1987). If the methods are invalid, so is the critique. The concept "fake news" is truly fake news. Yet if there are different ways of knowing and making sense, which there manifestly are - look no further than the school curriculum - and if these embody different tests of truth, then truth itself may also be plural, epistemically if not morally.

Some of Jerome Bruner's most interesting work towards the end of his long life provides a perspective on these matters, though he was no post-modernist. He reduces humankind's ways of investigating, knowing and understanding to just two modes:

One verifies by appeal to formal verification procedures and empirical truth. The other establishes not truth but truthlikeness or verisimilitude ... One mode is centered around the narrow epistemological question of how to know the truth; the other around the broader and more inclusive question of the meaning of experience (Bruner, 2006, p. 116).

Bruner named the first mode logico-scientific or "paradigmatic" and the second mode "narrative", which recalls anthropologist Clifford Geertz's definition of culture as "the stories we tell ourselves about 
ourselves" (Geertz, 1975). (Not coincidental: the admiration of these two giants was mutual (Mattingly, Lutkehaus \& Throop, 2008). But apart from the obvious cases of, say, mathematics and science, assigning school subjects to one or other of Bruner's modes isn't straightforward. History, being both evidential and narrative, can be in either mode or both, while locating the social sciences, despite their name, is equally problematic; and in mentioning F.R. Leavis earlier I noted his exemplifying the educated literary response as a combination of subjective/intersubjective judgement and evidence from textual scrutiny. Leavis's "common pursuit of true judgement" placed him closer to the toughness of philosophical analysis than to the genially idiosyncratic study of literature as pursued by others of his generation (Tanner, 1975; Joyce 1988).

Bruner's paradigmatic/narrative distinction might appear to reinforce the old opposition of "fact" and "fiction", or of what is supposedly true and what is manifestly made up. But would those to whom Margaret Attwood's The Handmaid's Tale speaks so vividly allow that because it's a work of fiction it doesn't deal in truth? Would we be happy for this sweeping judgement to be passed on all those poets, novelists and dramatists, and indeed artists and musicians, whose illuminating insights into the human condition take us beyond the reach of the social sciences, and show inner lives rather than merely attach labels to them? (Leavis again: "This is so, isn't it ... Yes, but ..."). In the words of Scottish novelist Ali Smith:

Fiction and lies are the opposite of each other ... Lies go out of their way to distort, or to turn you away from, the truth. Fiction is one of our ways to get to truths that are really difficult to talk about, that we haven't yet been able to articulate, or see; truths that we come to articulate via a story. (Smith 2018).

Not fact versus fiction, then, but fact and fiction versus lies, with both fact and fiction aspiring to truth, albeit to truths of different kinds, while lies fabricate it. But once again there's a problem of definition - fiction as something made up, and fiction as literary genre. Ali Smith is talking about fiction as literary genre, but the colloquial opposition of fact and fiction fails to make that distinction, thereby denying the truths that serious fiction, as opposed to mere entertainment, explore and expose, and relegating Bruner's narrative mode and Geertz's "stories we tell ourselves about ourselves" to the outer circle of trust.

But let us be clear. When commentators complain of "truth decay" and "the death of truth" they speak not of a universal epistemic and moral collapse but of a localised political or media malaise, or in academic circles a post-modernist turn. To most people truth really does matter, and they see it in terms of trust as much as evidence. Today's truth decay is about the behaviour of the body politic and sections of the print and digital media. It is about people who destroy trust by spreading falsehood and giving comfort to the cynical relativism of "fake news" and the "alternative fact". For the rest of us, including teachers and students, keeping faith with the enlightenment may be the best we can do.

\section{Conclusion}

Democracy is fragile and history cautions us against complacency about its prospects. Playing on voters' worst instincts and deepest fears self-styled "strong" leaders fan the flames of division and intolerance, marginalise dissenting voices, debase language and argument, and treat truth with contempt. The collision of this discourse with what is aspired towards in schools and universities is reminiscent of the darker decades of the $20^{\text {th }}$ century, Eric Hobsbawm's "age of extremes" (Hobsbawm, 1995), when H.G. Wells warned that "human history becomes more and more a race between education and catastrophe" 
(Wells, 1920), and Joseph Stalin retorted: "Education is a weapon whose effects depend on who holds it in his hands and at whom it is aimed" (Stalin and Wells, 1937). ${ }^{4}$

The scenario, then, is hardly new, but with a screen in every hand allied to a highly addictive technology, $21^{\text {st }}$ century mass communication possesses power and penetration far beyond what was conceivable in the $20^{\text {th }}$. Yet, by the same token, the sheer volume of information now accessible affords countervailing opportunities to challenge and correct, and behind every purveyor of fake news or alternative facts lurks a fact checker.

At the end of his vast and prescient 1990s trilogy The Information Age, Manuel Castells concluded that although the enlightenment dream seems forever frustrated by the "extraordinary gap between our technological overdevelopment and our social underdevelopment", it nevertheless remains within reach; for "there is no eternal evil in human nature" and "there is nothing that cannot be changed by conscious, purposive social action" (Castells, 1998, pp. 359-60). Dialogue is not a panacea, but it is indeed "purposive social action" as well as a vital ingredient of effective teaching and a worthy educational end in itself, and hence a manifesto for hope. Dialogue is essential to our response to the current cultural crisis; but only if it attends rigorously to those of its ingredients that are currently under most sustained attack: language, voice, argument and truth.

\section{References}

Adamson, S., Alexander, G.R. and Ettenhuber, K. (Eds.). (2007). Renaissance figures of speech. Cambridge: Cambridge University Press.

Alexander, R.J. (2001). Culture and pedagogy. Oxford: Blackwell.

Alexander, R.J. (2006). Education as dialogue: Moral and pedagogical choices for a runaway world. Hong Kong and York: Hong Kong Institute of Education with Dialogos.

Alexander, R.J. (2008). Essays on pedagogy. London: Routledge.

Alexander, R.J. (ed). (2010a). Children, their world, their education: Final report and recommendations of the Cambridge Primary Review. London: Routledge.

Alexander, R.J. (2010b). Speaking but not listening? Accountable talk in an unaccountable context, Literacy 44(3), 103-11.

Alexander, R.J. (2014). Evidence, policy and the reform of primary education. Forum 56(3), 349-375.

Alexander, R.J. (2015). Dialogic pedagogy at scale: Oblique perspectives, in Resnick, L.C., Asterhan, C. and Clarke, S. (Eds.), Socialising Intelligence Through Academic Talk and Dialogue. Washington DC, AERA, 413-423.

Alexander, R.J. (2017). Towards dialogic teaching: Rethinking classroom talk ( $5^{\text {th }}$ edition). York: Dialogos.

Alexander, R.J. (2018). Developing dialogue: Genesis, process, trial. Research Papers in Education, 33(5), 1-38.

Alexander, R.J., Hardman, F., Hardman, J., Longmore, M. and Rajab, T. (2017). Changing talk, changing teaching: Interim report from the in-house evaluation of the CPRT/UoY Dialogic Teaching Project. York: Cambridge Primary Review Trust and University of York.

4 The juxtaposition of these quotations is not contrived. H.G. Wells met and interviewed Stalin in 1934, and the encounter produced Stalin's infamous response quoted above. See New Statesman, 18 April 2014. 
https://www.robinalexander.org.uk/wp-content/uploads/2017/07/Alexander-et-al-EEF-in-houseinterim-report-final-170714.pdf

Althusser, L. On the reproduction of capitalism: Ideology and ideological state apparatuses, trans. and ed. G.M. Goshgarian. Brooklyn, NY: Verso.

Arendt, H. (2004). The origins of totalitarianism. New York: Schocken Books.

Atkinson, P. and Delamont, M. (1977). Mock-ups and cock-ups: The stage management of guided discovery instruction. In P.Woods and M.Hammersley, School Experience: explorations in the sociology of education. London: Croom Helm, 87-108.

Auden, W.H. (1991). September 1, 1939, in Collected Poems. London: Penguin.

Bakhtin, M.M. (1986). Speech genres and other late essays. Austin, TX: University of Texas.

Ball, S.J. (1990). Politics and policy-making in education. London: Routledge.

Bernstein, B. (1990). The structuring of pedagogic discourse (Class, codes and control, Vol 4). London: Routledge.

Bourdieu, P. and Passeron, J.-C. (1990). Reproduction in education, society and culture. London: Sage.

Bowles, S. and Gintis, H. (1976). Schooling in capitalist America: Educational reform and the contradictions of economic life. London: Routledge.

Boyd, M.P. and Markarian, W.C. (2015). Dialogic teaching and dialogic stance: Moving beyond interactional form. Research in the Teaching of English 49(3), 279-296.

Bruner, J.S. (2006). In search of pedagogy, Volume II. London: Routledge.

Carter, R. (1997). Investigating English discourse. London: Routledge.

Castells, M. (1998). End of millennium (The information age: Economy, society and culture, Volume 3). Oxford: Blackwell.

Cazden, C. (2001). Classroom discourse: The language of teaching and learning. Portsmouth $\mathrm{NH}$, Heinemann.

Committee for Linguistics in Education (2019). Language analysis in schools. http://clie.org.uk/language analysis/ (Accessed 7.2.19)

Condor, S Tileaga, C., \& Billig, M. (2013). Political rhetoric. In L.Huddy, D.O.Sears and J.S.Levy (eds) The Oxford handbook of political psychology. Oxford, Oxford University Press. DOI: 10.1093/oxfordhb/9780199760107.013.0009. (Accessed 7.2.19).

Crystal, D. (2018) The case for language analysis in schools. Paper for the event UKLO and Language Analysis. British Academy, 27 February. http://clie.org.uk/2018-2meeting/ .(Accessed 7.2.19).

Dawes, L., Mercer, N. and Wegerif, R. (2004, $2^{\text {nd }}$ edition). Thinking Together: a programme of activities for developing speaking, listening and thinking skills for children aged 8-11. Birmingham: Imaginative Minds Ltd.

Delpit, L. (1988). The silenced dialogue: Power and pedagogy in educating other people's children. Harvard Educational Review, 58(3), 280-299.

Dewey, J. (1997). [1916] Democracy and Education: An introduction to the philosophy of education. Free Press. 
Edwards, A.D. and Westgate, D.P.G. (1994). Investigating classroom talk. London: Falmer Press.

Edwards, J. (1989) Language and disadvantage (2 ${ }^{\text {nd }}$ edition). London: Cole and Whurr.

Fisher, R. (2008). Teaching Thinking: Philosophical enquiry in the classroom. London: Continuum.

Freire, P. (1970). Pedagogy of the oppressed. London: Bloomsbury.

Geertz, C. (1975). The interpretation of cultures London: Hutchinson.

Giroux, H.A. (2011). On critical pedagogy today. London: Bloomsbury.

Gregory, M.R. (2007). Normative dialogue types in philosophy for children. Gifted Education International 22, 160-171.

Grice, H.P. (1975). Logic and conversation, in P.Cole and J.Morgan (eds). Syntax and semantics, Volume 3, Speech Acts. New York: Academic Press.

Habermas, J. translated by F.Lawrence (1987). The philosophical discourse of modernity. Cambridge: Cambridge University Press.

Hardy, T. (1916). Far from the madding crowd. London: Macmillan.

Hirsch, E.D. (1988). Cultural literacy: What every American needs to know. New York: Vintage Books.

Hobsbawm, E. (1995). The age of extremes: The short twentieth century. London: Abacus.

Howe, C., \& Abedin, M. (2013). Classroom dialogue: A systematic review across four decades of research. Cambridge Journal of Education, 43(3), 325-356.

House of Commons Digital, Culture, Media and Sport Committee (2018). Disinformation and 'fake News': Interim report. London: House of Commons.

Jay, T., Taylor, R., Moore, N., Burnett, C., Merchant, G., Thomas, P., Willis, B. and Stevens, A. (2017). Dialogic teaching: Evaluation report and executive summary. London: Education Endowment Foundation with Sheffield Hallam University https://educationendowmentfoundation.org.uk/public/files/Projects/Evaluation Reports/Dialogic T eaching Evaluation Report.pdf (accessed 22.1.19).

Joyce, C. (ed). (1988). Leavis and philosophy. Bishopstone: Edgeways Books.

Kakutani, M. (2018). The death of truth. London: William Collins.

Kennedy, G.A. (1999). Classical rhetoric and its Christian and secular tradition. Chapel Hill: University of North Carolina Press.

Kenway, J. (1990). Education and the right's discursive politics: Private versus state schooling. In S. Ball (Ed.), Foucault and Education: disciplines and knowledge. London: Routledge.

Kessler, G., Rizzo, S. and Kelly, M. (2018). President Trump has made over 5000 false or misleading claims. Washington Post, 13 September.

Kim, M-Y. and Wilkinson, I.A.G. (in press). What is dialogic teaching? Constructing, deconstructing and reconstructing a pedagogy of classroom talk. Learning, Culture and Social Interaction.

Kuhn, D., Wang, Y. and Li, H. (2011). Why argue? Developing understanding of the purposes and values of argumentative discourse. Discourse Processes 48(1), 26-49. 
Lefstein, A., Pollak, I. and Segal, A. (2018). Compelling student voice: dialogic practices of public confession. Discourse: Studies in the Cultural Politics of Education, DOI 10.1080/01596306.2018.1473341.

Lefstein, A. and Snell, J. (2014). Better than best practice: Developing teaching and learning through dialogue. London: Routledge.

Levitsky, S, and Ziblatt, D. (2018). How democracies die. New York: Crown.

Lipman, M. (2003). Thinking in education ( $2^{\text {nd }}$ edition). New York: Cambridge University Press.

Mattingly, C., Lutkehaus, N.C., \& Throop, C.J. (2008). Bruner's search for meaning: A conversation between psychology and anthropology. Ethos, 36(1), 1-28.

Matusov, E. (2018). Mapping dialogic pedagogy: Instrumental and non-instrumental education. In A.Rose and J.Valsiner (eds), The Cambridge handbook of sociocultural psychology ( $2^{\text {nd }}$ ed). 274-301. Cambridge: Cambridge University Press.

Mayall, B. (2010). Children's lives outside school and their educational impact. In R.J.Alexander, C.Doddington, J.Gray, L.Hargreaves and R.Kershner (Eds.), The Cambridge Primary Review research surveys. London: Routledge, 49-82.

McCarthy, M. and Carter, R. (2001). Ten criteria for a spoken grammar. In E.Hinkel and S.Fotos (eds). New perspectives on grammar teaching in second language classrooms. Mahwah, N.J: Lawrence Erlbaum, 5175.

Mercer, N. (2000). Words and Minds: how we use language to think together. London: Routledge.

Mercer, N. and Dawes, L. (2008). The value of exploratory talk. In N.Mercer and S.Hodgkinson (eds). Exploring Talk in School. London: Sage, 55-72.

Mercer, N. and Littleton, K. (2007). Dialogue and the development of children's thinking: a sociocultural approach. London: Routledge.

Michaels, S. and O'Connor, C. (2012). Talk Science primer. Cambridge MA: TERC.

Michaels, S. and O'Connor, C. (2015). Conceptualizing talk moves as tools: Professional development approaches for academically productive discussions In L.B.Resnick, C.S.C.Asterhan, and S.N.Clarke (Eds.), Socializing intelligence through academic talk and dialogue. Washington DC: AERA, 347-61.

Michaels, S., O'Connor, C. and Resnick, L.B. (2008). Deliberative discourse idealized and realized: Accountable talk in the classroom and civic life. Studies in Philosophy and Education, 27(4), 283297.

Mortimer, E., \& Scott, P. (2003). Meaning making in secondary science classrooms. Maidenhead: Open University Press)

Nystrand, M., with Gamoran, A., Kachur, R. and Prendergast, C. (1997). Opening Dialogue: Understanding the dynamics of language and learning in the English Classroom. New York: Teachers College Press.

Ofsted (2018). School inspection handbook. London: Ofsted.

O'Keefe, G.S. and Clarke-Pearson, K. (2011) The impact of social media on children, adolescents, and families: American Academy of Pediatrics clinical report. Pediatrics, 127(4). http://pediatrics.aappublications.org/content/127/4/800 (accessed 6.1.19). 
Orwell, G. (1968). [1946] Politics and the English language, in S.Orwell and I.Angos (eds). The collected essays, letters and journalism of George Orwell. New York: Harcourt, Brace, Javonovich, 127139.

Osborne, J. (2015). The challenges of scale. In L.B.Resnick, C.S.C.Asterhan and S.N.Clarke (Eds.), Socializing intelligence through academic talk and dialogue. Washington DC: AERA, 403-414.

Park, Michaels, Affolter and O'Connor (2017). Traditions, research and practice supporting academically productive classroom discourse. Oxford Research Encyclopedia of Education, December. Oxford University Press.

http://education.oxfordre.com/view/10.1093/acrefore/9780190264093.001.0001/acrefore9780190264093-e-21 (accessed 1.9.18).

Popper, K.R. (1963). Conjectures and refutations: The growth of scientific knowledge. London: Routledge and Kegan Paul.

Qualifications and Curriculum Authority (eds). (2004), Introducing the grammar of talk. London: QCA.

Resnick, L.B. (2015). Talking to learn: Te promise and challenge of dialogic teaching, in L.B.Resnick, C.S.C.Asterhan and S.N.Clarke (eds). Socializing intelligence through academic talk and dialogue. Washington DC: AERA, 441-450.

Resnick, L.B., Asterhan, C.S.C. and Clarke, S.N., (2015). Talk, learning and teaching, in L.B.Resnick, C.S.C.Asterhan and S.N.Clarke (Eds) Socializing intelligence through academic talk and dialogue. Washington DC: AERA, 1-12.

Resnick, L., Michaels, S. and O'Connor, C. (2010). How (well structured) talk builds the mind, in R.Sternberg and D.Preiss (eds). From genes to context: New discoveries about learning from educational research and their applications. New York: Springer.

Reznitskaya, A., Kuo, L., Glina, M., \& Anderson, R. C. (2009). Measuring argumentative reasoning: What's behind the numbers? Learning and Individual Differences, 19, 219-224.

Reznitskaya, A. and Wilkinson, I. (2017). The most reasonable answer: Helping students build better arguments together. Cambridge MA: Harvard University Press.

Savage, M. (2019) Health secretary tells social media firms to protect children after girl's death. The Guardian, 26 January. https://www.theguardian.com/politics/2019/jan/26/matt-hancock-facebooksocial-media-suicide-self-harm-young-people. (Accessed 26.1.19).

Schopenhauer, A., ed. A.C.Grayling (2004). [1831] The art of always being right. London: Gibson Square Books.

Schwarz, B.B. and Baker, M.J. (2017). Dialogue, argumentation and education: History, theory and practice. New York: Cambridge University Press.

Segal, A. and Lefstein, A. (2015). Exuberant voiceless participation: Dialogic sensibilities in the Israeli primary classroom. Working Papers in Urban Language and Literacies 156. London: King's College.

Segal, A., Pollak, A. and Lefstein, A. (2016). Democracy, voice and dialogic pedagogy: The struggle to be heard and heeded, Language and Education, DOI: 10.1080/09500782.2016.1230124

Simon, J. (1966). Education and society in Tudor England. Cambridge: Cambridge University Press. 
Smith, A. (2018), quoted in media release from the Edinburgh International Book Festival, 21 August. https://www.edbookfest.co.uk/news/ali-smith-fiction-is-one-of-our-ways-to-get-to-truths-that-arereally-difficult-to-talk-about . (Accessed 24.9.18).

Spender, D. (1980). Man made language. London: Routledge.

Stalin, J. and Wells, H.G. (1937). Marxism vs liberalism: an interview (Transcript of interview in 1934). New York: New Century Publishers.

http://www.rationalrevolution.net/special/library/cc835 44.htm (accessed 24.9.18).

Tanner, M. (1975). Literature and philosophy, New Universities Quarterly, 30:1.

Toulmin, S. (2003). The uses of argument. Cambridge: Cambridge University Press.

Washington Post (2019). The Fact Checker's ongoing database of the false or misleading claims made by President Trump since assuming office.

https://www.washingtonpost.com/graphics/politics/trump-claimsdatabase/?noredirect=on\&utm term=.ab9ee6608cc8 (accessed 21.1.19).

Walton, D. (2013). Methods of argumentation. Cambridge: Cambridge University Press.

Welch, K.E. (1990). The contemporary reception of classical rhetoric: Appropriations of ancient discourse. Hillsdale, NJ: Lawrence Erlbaum.

Wells, G. (1999). Dialogic inquiry: Toward a sociocultural practice and theory of education. Cambridge: Cambridge University Press.

Wells, H.G. (1920). The outline of history, Vol 2. George Newnes.

\section{(cc) EY}

New articles in this journal are licensed under a Creative Commons Attribution 4.0 United States License.

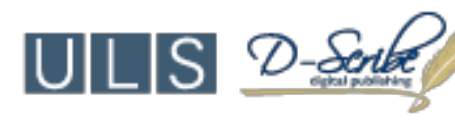

This journal is published by the University Library System, University of Pittsburgh as part of its D-Scribe Digital Publishing Program and is cosponsored by the University of Pittsburgh Press. 